\title{
INNOVATION AND ENTREPRENEURSHIP POLICIES AND GENDER EQUITY*
}

\author{
Barbara Liberda**, Olga Zajkowska***
}

\begin{abstract}
Background. Gender inequality hinders economic growth by lowering the pool of potential talents for production, through distorted access of one gender to education, employment, entrepreneurship, and creation of innovation. Research on policies on entrepreneurship, innovation and gender is of great importance for deciding on the best policy mix to diminish losses of welfare due to gender inequality.
\end{abstract}

Research aims. The aim of this paper is to examine how the policies towards innovation and entrepreneurship in Europe address the issue of gender equality. The question we put is whether entrepreneurship-targeting and innovation-targeting policies are gender-oriented, gender-neutral, or gender-indirect-discriminating.

Methodology. Our focus is on the intersection of the areas of innovations, entrepreneurship, and gender. We analyse models of innovation systems: National Innovation Systems, Tripple Helix, and Quadruple Helix Models and discuss if they address gender equality in innovations.

Key findings. We claim that a gender perspective is missing in policies towards innovation and entrepreneurship. Innovation policies in Europe target mostly male-dominated industries. The paper concludes that science-based policies on entrepreneurship and innovation should incorporate gender equality as their structural feature.

Keywords: policy, entrepreneurship, innovation, gender inequality, National Innovation Systems, Tripple Helix Model, Quadruple Helix Model.

* Authors gratefully acknowledge the funding support from the INNOGEND project funded from EEA and Norway Grants in the Polish-Norwegian Research Program operated by the National Centre for Research and Development.

${ }^{* *}$ University of Warsaw. E-mail: barbara.liberda@uw.edu.pl

**** Warsaw University of Life Sciences. E-mail: olga_zajkowska@sggw.pl 


\section{INTRODUCTION}

We investigate whether policies supporting entrepreneurship and innovation account for gender equality. The rationale is that gender inequality may hinder economic growth by lowering the pool of potential talents for production, entrepreneurship, and innovation.

Empirical literature has shown that gender inequalities in education and employment decrease economic growth (Dollar, 1999; Klasen, 2002; Klasen and Lamanna, 2009; OECD, 2006; IMF, 2013; WB, 2001, 2011). Assuming that talents are equally distributed among males and females, the barriers in access to education, employment, and entrepreneurship for women reduce the pool of talents for productive allocation. In effect women are underrepresented in all occupations and mainly in highly productive activities and in innovation.

Economic development and women empowerment are closely related according to Duflo (2012): development plays a positive role in decreasing gender inequality and, vice versa, empowering women may benefit development. Though, Duflo argues that these linkages are too weak to be self-sustaining, and that policies aimed at gender equality are continuously needed.

Based on cross-country and panel regressions for a period of 1960-2000, Klasen and Lamanna (2009) found that gender gaps in employment have an increasing effect on differences in economic growth between regions, with Middle East and North Africa as well as South Asia suffering from slower growth in female employment.

In the OECD countries, the increase in the years of education of the total population and a more equal ratio of education by gender have a positive influence on per capita output growth. The potential effect of increased female labour force participation on economic growth was calculated by Thévenon et al. (2012). If male and female labour force participation rates fully converged across OECD countries in the next 20 years, this would lead to an additional gain in GDP of $12 \%$ by 2030 on average for the OECD countries. Furthermore in order to reach macroeconomic gains from gender equity, the IMF (2013) calls for implementing policies that remove labour market distortions and give women the opportunity to develop their potential talent.

Theoretical considerations on the effects of gender inequality on individual welfare and aggregate labour productivity are based 
on occupational choice models of Roy (1951), Lucas (1978), Rosen (1982), and Jovanovic (1994). Esteve-Volart (2000, 2004) analysed the distortions in the allocation of talent between managerial and unskilled positions and in human capital investment based on Rosen's model (1982) on the individual's choice between becoming a manager or a worker.

In the model, agents are born with different managerial talents. If women cannot get access to managerial positions, the equilibrium wage declines, and the average level of managers' talent declines as well. Lower average managerial talent and lower female human capital accumulation hinder economic growth, through effects on technological progress and innovation, and imply a reduction in per capita GDP. Esteve-Volart presents evidence based on cross-country regressions (2000) and on panel-data regressions (2004) for India's states that are consistent with the model's prediction that gender discrimination is an inefficient practice.

Similar results on gender gaps in entrepreneurship were obtained by Cuberes and Teignier (2016) who simulate an occupational choice model with heterogeneous agents in entrepreneurial ability, where agents choose to be workers, self-employed, or employers. Their model is based on the span-of-control framework of Lucas (1978), where agents are endowed with a random entrepreneurship skill that determines their optimal occupation. It is assumed that men and women have the same talent distribution, but the model imposes frictions on women's opportunities. Cuberes and Teignier examine the quantitative effects of gender gaps in entrepreneurship and labour force participation on aggregate productivity and per capita income.

They find out that gender gaps in occupational choice affect aggregate productivity negatively due to the fall in the average talent of entrepreneurs. Gender gaps in labour force participation reduce per capita income because they decrease the labour input. In the cross-country analysis, the model predicts an average income loss of $15 \%$ in the OECD sample, of which 2/5 is due to gaps in entrepreneurship. Gender gaps and their implied income losses differ across geographical regions. A total implied income loss in Middle East and North Africa is predicted at $38 \%$, of which $1 / 5$ is due to entrepreneurship gaps. In Central Asia the implied income loss is $10 \%$, of which $3 / 4$ is due to gaps in entrepreneurship (Cuberes and Teignier, 2016).

The strong proof of the positive effects of reducing gender inequality on aggregate labour productivity was provided by Hsieh et al. (2013) 
who measured the macroeconomic consequences of the convergence in the occupational distribution between white men and white and black women in the US from 1960 to 2008. They used a standard Roy (1951) model of occupational choice, augmented for labour market discrimination in employment and discrimination in the acquisition of human capital. Hsieh et al. (2013) find the positive effects of changing frictions implied by the observed occupational convergence resulting in smaller gender inequalities in earnings and productivity. These effects account for 15 to 20 percent of growth in US aggregate output per worker since 1960 .

Given the effects of gender inequality on individual welfare and macroeconomic productivity described above it is relevant to ask the question whether entrepreneurship-targeting and innovation-targeting policies are gender-oriented, gender-neutral, or gender-indirect-discriminating. In the next sections we present the key analytical models of innovation systems provided by the literature: National Innovation Systems, Tripple Helix Model, and Quadruple Helix Model. The models describe creation and diffusion of knowledge and innovation processes (Fagerberg \& Verspagen, 2009; Fagerberg, 2015). Innovation systems are analysed at several levels: national, regional, sectoral, technological (Carlsson et al., 2002; Bergek et al., 2008). We will examine how they address gender equality in innovations and entrepreneurship.

\section{BACKGROUND}

\section{Entrepreneurship and innovation by gender and policies}

In searching for publications for the purpose of this article we used mainly the ideas.repec.org database and Google Scholar. In the first step, we searched for articles and working papers based on the following key words: gender, innovation, entrepreneurship, policy, and evaluation. We received ca. 250 peer-reviewed articles and working papers. Then, we extended our analysis with policy reports. In the next step the pool of articles was reduced only to economic and policy papers.

Innovation research seems to be missing analyses of where innovation takes place, and who participates in innovation activity (Fagerberg et al., 2004). Consequently, the concept of gender and innovation has 
only recently gained a wider interest among researchers within the management and entrepreneurship fields (Alsos et al., 2013). Women and men are equally capable of contributing to research, entrepreneurship, and innovations. Nevertheless, often the women's contribution is not accounted for in the final outcomes. Several examples from the academia can be given. Inputs into science of Lise Meitner (Sime, 1996), Rosalind Franklin (Maddox \& Mcelheny, 2003), Margaret Reid (Yi, 1996) and many others are still underappreciated and undervalued.

Several measures have been implemented to assess gender imbalance in innovations and entrepreneurship (Alsos et al., 2013). Some of them describe conditions on universities like: share of female students by fields or disciplines, number and share of women in research institutions and universities, amount and share of grants handled by women. Other measures are business-related like fraction of female patent holders (Hunt et al., 2013). Another measures relate to the labour market, for example females' share in engineer-type occupations, self-employed women's share, fraction of female company owners, females' share in male-dominated industries (addressed by policies), or fraction of companies led in majority by women.

Entrepreneurial and innovative activities undertaken by both genders depend on institutional context. Interaction of national level institutions and attitude toward female labour freedom influence female entrepreneurship. Countries with larger female labour market participation and higher level of education have also higher female entrepreneurial activity (Chowdhury \& Audretsch, 2014).

Innovations can be reduced by extensive product and labour market regulations, but they can be enhanced by developed financial market support (Barbosa \& Faria, 2011). Thus, analysis of gender perspective in entrepreneurial and innovative policies should internalise institutional framework.

Entrepreneurs are not a homogeneous group. Entrepreneurial capacity is defined by several factors, which can have different outcomes for men and women:

1) The first group are factors describing individuals as entrepreneurs, like skills and motivations.

- Motivation of an entrepreneur is defined by: necessity to prevent poverty, threat of unemployment and social exclusion, opportunity to gain autonomy, personal profits, and an increase of wealth (Morris et al., 2006). 
- Motivation is shaped by aspirations. Hessels, Gelderen and Thurik (2008) show that different aspirations may have different drivers. Entrepreneurs are either necessity-motivated or motivated by a will to increase wealth. The latter ones are discouraged with the growth of welfare (Hessels et al., 2008).

- Innovations are generated mostly by opportunity driven entrepreneurs (DeTienne \& Chandler, 2007) but entrepreneurial motives change over time (Littunen, 2000). There exists a gender difference in entrepreneurial aspirations (BarNir, 2012), therefore men and women may react differently when treated with policies.

- Women are less likely to become entrepreneurs in countries where the public sector is larger. Restrictions on women empowerment may lower their aspirations and therefore reduce their entrepreneurial activities (Estrin \& Mickiewicz, 2011). Additionally, women face different than men family-related time constraints. Therefore, policies aiming at supporting women in entrepreneurial and innovative activities should be sensitive to these diversities.

2) The second group of factors shaping entrepreneurial capacity are micro level social structures and national level institutions (Klapper \& Parker, 2011).

- Social security systems are important welfare state institutions that can affect entrepreneurship. High level of social security may be discouraging for undertaking entrepreneurial or innovative activities (Hesselset al., 2008).

- Corruption can discourage economic activity and restrain an entrepreneur's growth aspirations but women are less willing to gain at the cost of public welfare (Anand et al., 2001).

- Stronger legal systems support female entrepreneurship (Chowdhury \& Audretsch, 2014). Stronger property rights encourage more entrepreneurial activities (Estrin \& Mickiewicz, 2011; Klapper \& Parker, 2011). Thus, it can be claimed that institutional frameworks are not gender-neutral.

- Traditional approach recommendations, which treat the firm as a representative agent without analysing the innovation 
process inside the firm, may have different outcomes for men and women (Fagenberg, 2005; Alsos et al., 2013). Examples of traditional instruments are taxes and subsidies.

- A part of the entrepreneurship gap is due to gender differences in access to capital and networks of contacts (Rost, 2011; Sauer \& Wilson, 2015).

- Gender should be addressed in policies explicitly (Kvidal \& Ljunggren, 2014). Articulation of gender in implementation of policies plays a crucial role in closing the innovation gap. It is because the outcomes of policies intended to be gender neutral may turn out to be gender-labelling or gender-biased. They may unintentionally support gender stereotypes and traditional gender roles.

- Individual entrepreneurship activity motivations differ from goals of policymakers, which are job creation, growth, or development on country level (Hessels et al., 2008). Therefore, policy learning is so important and each policy should be evaluated in the short and long term.

In most studies on entrepreneurship and innovations gender occurs only as a dummy variable (Aidis et al., 2010). However, many researchers claim that females may respond differently to economic interventions, conditional on their socio-economic status and other factors. Buvinic and Furst-Nichols (2014) provide a broad review of evaluation studies aiming at female empowerment. They show that more disadvantaged women need more intense treatment than other women to grow their businesses.

The policy design should be based on all available knowledge and take into account the current state of research. An example of a good information source is 2011 Global Entrepreneurship Monitor (GEM) report (Bosma et al., 2012) which provides several recommendations on policies and priorities to support entrepreneurship. Most of them point to the need of supporting women by:

- Simplifying government regulations. This may lead to reducing costs of running a company and support women since they have smaller access to capital than men (Bradley et al., 2013; Gicheva, 2011).

- Balancing a desire for economic security with reduced level of entrepreneurial activity (Estrin \& Mickiewicz, 2011; Fossen, 2012). 
- Facilitating participation of women and mature adults in entrepreneurship. Mature women are usually at a higher risk of long-term unemployment. Encouraging people in the age group of 50+ years to undertake entrepreneurial activities may be part of the solution to this problem.

In management literature gender theories are a relatively new concept which emerged in the late 70s. Many papers discuss gender relations in management of organisations. It has been recognised that management and managing are gendered although they seem gender-neutral. The suitable management approach to analyse policies, gender, and innovation issues is the gender-organisationsystem (GOS) perspective proposed by Fagenson (1990). It allows for theoretical and empirical analysis of gender relations and the socio-institutional system and underlines the dependencies between these factors.

Some authors (Schein, 2007; Powell et al., 2002) show the persistence of 'think manager-think male' attitudes and claim the need to incorporate both influence and inclusion factors in the analysis of female performance in management. Others (Farr-Wharton \& Brunetto, 2007) examine the role of trust on women's networking behaviour and assert the need to support women business networks. Nevertheless, gender has not been incorporated sufficiently into the mainstream management research and little attention in management literature is drawn to gender in the context of innovations.

Although, as we have shown above, there exists conclusive research on the entrepreneurship policy design, implementing the gender perspective into innovative entrepreneurship strategy is still an analytical construct. Policies addressing small and medium enterprises and policies addressing science and technology (S\&T) or research and development (R\&D) are still separated (Dahlstrand \& Stevenson, 2010) and do not include heterogeneous actors of entrepreneurial processes sufficiently. 


\section{METHOD}

\section{Using models of innovation systems for policy analysis}

Creating innovation requires nonstandard, out of the box thinking and questioning of the "natural" order of how things work. The innovation concept can be separated to some extent from the notion of entrepreneurship. We distinguish: product innovations (including innovative services and innovative goods), process innovations (including innovations within organisations and effective leadership), and social innovations. They are created differently and require different skills. Product innovations often require engineer knowledge while organisational innovations require managerial skills.

Skills are, in principle, gender neutral. However, research shows that women and men often undertake different innovation strategies. Women are often more likely to utilise a Learn/Innovate strategy while men are more likely to utilise the Learn/Acquire and Learn/Replicate strategies. There are differences in the innovativeness between these approaches, but they can be considered as equally efficient (DeTienne and Chandler, 2007).

Innovation processes are heavily affected by policies. National, regional and local laws, regulations, and other instruments may encourage or discourage innovativeness. And often innovation policies target mostly male-dominated industries (Lindberg, 2010). Therefore, we examine how models of innovation systems: National Innovation Systems, Tripple Helix, and Quadruple Helix Models account for gender equality in innovations and entrepreneurship.

National Innovation Systems (NIS) assign the leading role in innovation creation to companies (Lundvall et al., 2002). Most of the traditional innovation policies are designed based on National Innovation Systems. They treat the company as an entity where processes are improved (Fagerberg, 2015). Actors in these processes can be seen as representative agents. The gender perspective is therefore rarely incorporated and does not provide useful insight (Blake \& Hanson, 2005). Additionally, critiques of National Innovation Systems underline a lack of ability of investigating internal processes and investments (Guan \& Chen, 2012; Alsos et al., 2013).

The Triple Helix is an analytical model describing government-industry-university relations in explaining the innovation process 
(Etzkowitz \& Leydesdorff, 2000). The main advantage of this model is that The Triple Helix model does not assign a leading role to any of the three actors.

The Quadruple Helix model (Figure 1) extends the Tripple Helix model by including non-government/non-profit organisations (NGOs) and bottom-up initiatives into entrepreneurial and innovation processes (Lindberg, 2014). The Quadruple Helix model incorporates gendered norms into the analysis (Lindberg et al., 2014). Non-government organisations are seen as helpful entities in closing both entrepreneurial and innovation gender gaps. They may bridge women-led small and medium enterprises (SMEs) with other actors in the model (government and science/university). Non-government organisations provide networking, education, and work-life reconciliation of entrepreneurs/ innovators which is particularly important for women.

Within the Quadruple Helix model framework it is possible to analyse innovations in the public sector, using a broader definition of innovations and incorporating more aspects of the innovative processes. The Quadruple Helix model allows to design women inclusion into the process. Lindberg (2014) stresses the importance of bottom-up initiatives in supporting disadvantaged/marginalised actors of the entrepreneurial/innovation process. Therefore, entrepreneurship and innovations supporting policies should be analysed and evaluated within the framework of the Quadruple Helix model.

Elements of the Quadruple Helix model are described in the next section in the context of gender perspective in innovation policies.

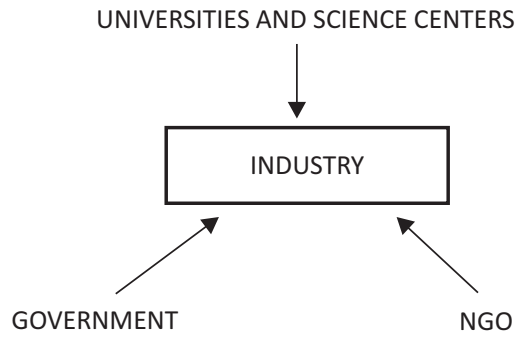

Figure 1. Quadruple Helix Model

Source: Author's work

The policies aiming to support women in entrepreneurial and innovative activities are evaluated according to their sensitivity to both differences within and between genders. 


\section{RESULTS}

\section{Government-based policies (mainstream policies)}

Governments play a crucial role in enhancing and supporting innovations on the national level. Most 'traditional' instruments, consistent with the National Innovation Systems' approach, address the policy goals at company level. Examples are tax cuts and subsidies. Within this approach specific institutions (Innovation Norway, ${ }^{*}$ Swedish Agency for Economic and Regional Growth, ${ }^{* *}$ VINNOVA ${ }^{* * *}$ ) and programs targeting innovation support (COSME, Vanguard Initiative 'New Growth through Smart Specialization, ${ }^{* * * *}$ Austrian PPPI, ${ }^{* * * * *}$ Dutch 'To The Top') are introduced. They aim to support women but their efficiency is usually not evaluated.

The government may also be an entity raising awareness, supporting good practices, targeting specific groups, and providing work-life balance support, like: March 2014 European Council: STEM (Craig et al., 2007), Horizon 2020 "Promoting Gender Equality in Research and Innovation, ${ }^{* * * * * * *}$ Women Resource Centres (Danilda, 2011). Yet, it is difficult to assess the outcomes of these programs.

\section{University and research institute based policies}

In the innovation process gender is mostly recognised in research, publications, and patents. Gender gap in university research is broadly discussed and female participation in science is measured by several institutions, like Eurostat or EMBO. ${ }^{* * * * * * *}$ What seems to be a relevant question is whether attracting women into science, technology, engineering, and mathematics (STEM) is a successful policy. Frietsch et al. (2009) show that although the gender gap in publication is closing, the gender gap in patenting seems to be stable.

\footnotetext{
* http://www.innovasjonnorge.no/ (access: 18.07.2017).

** http://www.tillvaxtverket.se/ (access: 18.07.2017).

*** http://www.vinnova.se/ (access: 18.07.2017).

***** http://www.s3vanguardinitiative.eu (access: 18.07.2017).

******* http://www.ioeb.at/ (access: 18.07.2017).

******* https://ec.europa.eu/programmes/horizon2020/en/h2020-section/promoting-gender-equality-research-and-innovation (access: 18.07.2017).

********* http://wils-database.embo.org/ (access: 18.07.2017).
} 
In line with these numbers Busolt and Kugele (2009) claim that in order to fully utilise women's innovation potential it is not enough to increase the number of female researchers. On subsequent stages of their careers female researchers do not obtain the proportional amount of research grants and other resources in relation to their share among scientists. The further on the career path the smaller is the fraction of female scientists (described as a leaking pipe). Therefore, attracting girls into science, technology, engineering, and mathematics education (STEM) may not be enough. Female researchers should be provided with an equally proportional share of resources and the same working conditions as male researchers.

In projects funded by the European Commission much attention is devoted to increasing female participation in research. " The aim is to increase the number of women applying for grants and to increase the fraction of women as research team leaders. Several programs are dedicated/designed only for women, like programs provided by The L'Oréal Corporate Foundation. ${ }^{* *}$ The European Commission has set a workgroup "Women and Science" to coordinate actions promoting women in research. Since the $5^{\text {th }}$ Framework Programme, female participation in research projects has been carefully monitored. The aim was to reach $40 \%$ of women among the investigators. A similar goal was set for Maria Curie scholarships. ${ }^{* * *}$ Also Horizon 2020 aims promoting gender equality and innovations.

Nevertheless, it is worth noticing that policies of quotas although necessary may not be sufficient to increase the number of female scientists being team leaders or may bring opposing and surprising results. Ruest-Archambault (2008) shows that in Europe the proportion of women researchers is negatively correlated with: presence of a unit for women in science at the Ministry of Science and the existence of quotas, targets, and mentoring schemes, special grants for women, or paternity leave.

In 2008 the European Platform of Women Scientists, being an umbrella organisation aiming at networking of female scientists, proposed a list of best practices and recommendations which should be implemented by institutions on national level in order to attract and keep more female scientists:

\footnotetext{
* See: European Parliament resolution of 21 May 2008 on women and science.

** http://www.loreal.com/csr-commitments/foundation (access: 18.07.2017).

${ }^{* * * *} \mathrm{http} / /$ ec.europa.eu/research/mariecurieactions/about-en (access: 18.07.2017).
} 
- Gender-sensitive teaching based on the concepts of equality and diversity. Children and teenagers should be encouraged to undertake STEM education irrespective of their gender. Additionally, as shown by Fogelberg Eriksson (2014), incorporating the gender perspective into teaching is an organisational innovation which can further trigger innovative processes.

- Importance of the integration of the family perspective in career development. Reducing work-life tension may attract female scientists to research careers.

- Incentives for female PhDs and post-docs leading to more female assistant professors- and several other propositions like quotas in employment, promotions, and funding research grants.

- Promoting female networking aiming to incorporate more women into research teams and mentoring to encourage and support female leaders in science.

- Equal pay for jobs for men and women.

\section{NGOs, civil society, and bottom-up initiatives}

Extending the tripple helix model into the quadruple helix model Lindberg (2014) points out to the need of including civil society initiatives and NGOs into the innovation process analysis. They link women-led small and medium enterprises (SMEs) with governmental and academic entities. Good examples are collaborative platforms for women-led small and medium enterprises or for female researchers.

Bottom-up initiatives are able to support women's entrepreneurship and innovations at a regional level. They are usually started by civil initiatives or NGOs. These activities are in line with the fourth element of analytical Quadruple Helix model. Bottom-up initiatives implement most of the policy recommendations designed for governments. Most common are networking and encouraging women's entry into STEM. Several online databases of female experts were founded in recent years. Good examples are \#ChoosePossibility Project* being a list of female founders CEOs in tech companies or ekspertki.org being a Polish database of women engaged in science. Other forms of networking gaining popularity are those combined with educational activities,

\footnotetext{
* https://choosepossibility.com/ (access: 18.07.2017).
} 
for example Geek Carrots or Django Girls - informal organisations devoted to develop programming skills among girls.

Some initiatives overcome the problem of gender bias in capital access. An example is INSTRUMENTL* - a crowdfunding platform invented by female researchers to collect money for research by academics. Awareness of companies is also growing, for example, gender balanced scorecards are introduced. Although, we can give several examples of bottom-up initiatives, we have not come across any evaluation study of their efficiency. These initiatives are still a new phenomenon and the literature lacks sufficient analysis of the topic.

Although each of the previous elements of the Quadruple Helix model gives a promising area of analysis aiming at improvement of policies supporting innovations, Borrás and Edquist (2013) calls for taking into consideration interdependencies of these elements. Fagerberg (2004) proposes applying a cross-disciplinary perspective into discussion and research on innovations.

There is a strong need to create codes of conduct for firms, universities, or public research organisations. Also public-private partnerships sharing costs, benefits, and risks in the provision of specific public goods should be supported. Based on several countries' case-studies Borrás and Edquist (2013) point out that there does not exist one single instrument boosting innovativeness and what is needed is a policy mix as the combination of several innovation policy instruments. This conclusion is a wrap-up of the analytical concept of the Quadruple Helix model.

Few studies on innovation policy evaluation so far have investigated the gender perspective (Alsos et al., 2013). Even fewer studies have been peer-reviewed and published (Blake \& Hanson 2005; Kvidal \& Ljunggren, 2014; Nählinder et al., 2012). Most of innovation policy studies incorporating the gender perspective exist as reports ("Promoting Innovation - Vinnova", 2015; Danilda, 2011), conference papers or working papers (Pettersson, 2007). The Oxford Handbook of Innovation (Fagerberg et al., 2004) and the Oslo Manual (OECD and Eurostat, 2005) almost do not use words like women or gender.

An implicit assumption made by most researchers is that innovations and innovation policies are gender-neutral. This assumption is

\footnotetext{
" https://www.instrumentl.com/ (access: 18.07.2017).
} 
rarely true. Most of innovation policies target specific sectors. Given gender segregation of the labour market, gender disparities in access to benefits of innovation policy tend to occur.

Researchers point put that the operationalisation of the concept of innovation is gender-biased (Nählinder et al., 2015). Government financial support and other instruments often target male-dominated industries and male-labelled sectors. Male-dominated sectors are measured mainly when innovations and innovation systems are analysed ("Promoting Innovation - Vinnova", 2015). Women participation in research projects is often invisible in the final research results (Turner, 2009).

Female researchers are also marginalised in the discourse on innovations (Blake \& Hanson, 2005) and innovation policy (Danilda, 2011; Kvidal \& Ljunggren, 2014). Gender-labelling affects recognition of female innovations (Nählinder et al., 2012). However, it is worth noticing that innovations occur in female-dominated industries or in the public sector (Nählinder, 2010). On the other hand, it is important not to treat women as an inferior or less significant group in research and innovation (Ahl, 2006).

Interesting aspects of incorporating the gender perspective into all elements of innovation process are described by Schiebinger and Schrauder (2011). They show several examples of enhancing results by incorporating the gender perspective, from a virtual pregnant women crash-test dummy to medical trials with control for gender.

Innovation policies design should be focused rather on promoting diversity than preventing discrimination. Even in gender-aware countries, like Finland or Denmark, innovation policies rarely point out gender inequality and perceive it as a problem (Pettersson, 2007). Gender inequalities and gender issues are seen as a women issue. Gender is not mainstreamed in innovation policies in the European countries.

Policy makers should create programs such as flexible training programs and policies of subsidised childcare and access to female mentors that better prepare women to succeed if they decide to undertake an entrepreneurial venture. 


\section{DISCUSSION \& CONCLUSIONS}

As talents are equally distributed among males and females, the gender inequalities in access to education, employment, entrepreneurship, and creation of innovation reduce the pool of talents for productive allocation and thus economic growth through effects on technological progress and innovation.

Research on policies on entrepreneurship, innovation, and gender is of importance for designing policies preventing losses of welfare due to gender inequality. Entrepreneurial and innovative activities undertaken by both genders depend on the institutional context. Innovation processes are heavily affected by policies.

In this paper we examine how policies supporting entrepreneurship and innovation account for gender equality.

We show that European policies usually do not address a gender perspective in innovations explicitly (Lisbon Agenda guidelines). The Oslo Manual uses the key word "gender" only once, on page 144, where innovation surveys are discussed: "It is recommended to collect data on human resources, from the perspective of both its composition (by qualification, type of occupation and gender) and its management." The document does not contain the key words "woman," "women," or "female." The Oslo Manual, which sets standards in innovations' measurement and analysis does not incorporate the gender perspective.

We find that innovation policies both at the European Union and country level target mostly male-dominated industries.

We argue that treating a firm as a representative agent has different outcomes for men and women due to gender differences in access to capital and networks of contacts and due to segregation of the labour market.

We claim that gender should be addressed in policies explicitly because the outcomes of policies intended to be gender neutral may turn out to be gender-labelling or gender-biased.

Only very few policy evaluation studies exist in literature in the area of gender and innovations. There has been no policy learning in this area (e.g. treating policies as hypotheses verified and adjusted over time), since not many such policies have been designed so far. Policy learning is important - policies should be evaluated in short and in the long term. 
We have shown that the multidisciplinary analytical approach is needed to design a policy mix on entrepreneurship, innovation, and gender. A promising conceptual model seems to be the Quadruple Helix model incorporating gender perspective over research and education, non-government organisations (NGOs), and civil society initiatives.

We conclude that in order to create a science-based policy on entrepreneurship and innovation it is essential to incorporate the gender perspective to fully exploit the innovative potential of all individuals.

The areas for future research are: designing policies that combine the dimensions of innovation, entrepreneurship, and gender as well as evaluation studies of existing and newly designed policies.

\section{REFERENCES}

Ahl, H. (2006). Why research on women entrepreneurs needs new directions. Entrepreneurship Theory and Practice, 30(5), 595-621.

Aidis, R., Estrin, S. \& Mickiewicz, T. (2010). Institutions, finance and the level of development: the impact on entrepreneurship in transition. Review of economics and institutions, 1(1), 1-26.

Alsos, G.A., Ljunggren, E. \& Hytti U. (2013). Gender and innovation: state of the art and a research agenda. International Journal of Gender and Entrepreneurship, 5(3), 236-256.

Anand, S., Knack, S., Young, L. \& Azfar, O. (2001). Gender and corruption. Journal of Development Economics, 64(1), 25-55.

Barbosa, N. \& Faria, A.P. (2011). Innovation across Europe: how important are institutional differences? Research Policy, 40(9), 1157-1169.

BarNir, A. (2012). Starting technologically innovative ventures: reasons, human capital, and gender. Management Decision, 50(3), 399-419.

Bergek, A., Jacobsson, S., Carlsson, B., Lindmark, S. \& Rickne, A. (2008). Analyzing the functional dynamics of technological innovation systems: a scheme of analysis. Research Policy, 37(3), 407-429.

Berglund, K., Gunnarsson, E., \& Sundin, E. (2012). Promoting Innovation: Policies, Practices and Procedures. Stockholm: Vinnova.

Blake, M.K. \& Hanson, S. (2005). Rethinking innovation: context and gender. Environment and Planning A, 37(4), 681-701.

Borrás, S. \& Edquist, Ch. (2013). The choice of innovation policy instruments. Technological Forecasting and Social Change, 80(8), 1513-1522. 
Bosma, N., Wennekers, S. \& Amorós, J.E. (2012). Global Entrepreneurship Monitor, 2011 Extended Report: Entrepreneurs and Entrepreneurial Employees across the Globe. London: Global Entrepreneurship Research Association (GERA).

Bradley, S.R., Gicheva, D., Hassell, L. \& Albert N. (2013). Gender Differences in Access to Private Investment Funding to Support the Development of New Technologies. Working Paper, 13-9. University of North Carolina at Greensboro, Department of Economics.

Busolt, U. \& Kugele, K. (2009). The gender innovation and research productivity gap in Europe. International Journal of Innovation and Sustainable Development, 4(2/3), 109.

Buvinic, M. \& Furst-Nichols, R. (2014). Promoting Women's Economic Empowerment: What Works? WPS7087. The World Bank.

Carlsson, B., Jacobsson, S., Holmén, M., \& Rickne, A., (2002). Innovation systems: analytical and methodological issues. Research Policy, Innovation Systems, 31(2), 233-245.

Chowdhury, F. \& Audretsch, D. (2014). Institution as looting apparatus: impact of gender equality and institutions on female entrepreneurship. Eurasian Business Review, 4(2), 207-225.

Communication from the Commission of 17 February 1999, Women and Science: Mobilizing Women to Enrich European Research.

Craig, A., Fisher, J. \& Lang C. (2007). ICT and Girls: The Need for a Large Scale Intervention Programme. ACIS 2007 Proceedings, 36.

Cuberes, D. \& Teignier, M. (2016). Aggregate effects of gender gaps in the labor market: A quantitative estimate. Journal of Human Capital, 10(1), 1-32.

Dahlstrand, A.L. \& Stevenson, L. (2010). Innovative entrepreneurship policy: linking innovation and entrepreneurship in a European context. Annals of Innovation \& Entrepreneurship, 1(1), 1-15.

Danilda, I. (2011). Innovation and Gender. Stockholm: Vinnova.

DeTienne, D.R., \& Chandler G.N. (2007). The role of gender in opportunity identification. Entrepreneurship Theory and Practice, 31(3), 365-386.

Dollar, D.G. (1999). Gender Inequality, Income, and Growth: Are Good Times Good for Women? WP20771. The World Bank.

Duflo, E. (2012). Women empowerment and economic development. Journal of Economic Literature, 50(4), 1051-1079.

Esteve-Volart, B. (2000). Sex discrimination and growth. IMF Working Paper, 00/84. International Monetary Fund.

Esteve-Volart, B. (2004). Gender Discrimination and Growth: Theory and Evidence from India. STICERD - Development Economics Papers - LSE. 
Estrin, S. \& Mickiewicz, T. (2011). Institutions and female entrepreneurship. Small Business Economics, 37(4), 397-415.

ETAN (2000). Report on Women and Science: Science Policies in the European Union: Promoting Excellence through Mainstreaming Gender Equality.

Etzkowitz, H. \& Leydesdorff, L. (2000). The dynamics of innovation: from national systems and 'Mode 2' to a Triple Helix of University-industry-government relations. Research Policy, 29(2), 109-123.

Fagenson, E.A. (1990). At the heart of women in management research: Theoretical and methodological approaches and their biases. Journal of Business Ethics, 9(4-5), 267-274.

Fagerberg, J. (2004). Innovation: A Guide to the Literature. In: J. Fagerberg, D. Mowery \& R. Nelson (eds.), The Oxford Handbook of Innovation (pp. 1-26). Oxford: Oxford University Press.

Fagerberg, J. (2015). Innovation Policy, National Innovation Systems and Economic Performance: In: Search of a Useful Theoretical Framework. Working Papers on Innovation Studies, 20150321. Centre for Technology, Innovation and Culture, University of Oslo.

Fagerberg, J. \& Verspagen, B. (2009). Innovation studies - the emerging structure of a new scientific field. Research Policy, 38(2), 218-233.

Farr-Wharton, R. \& Brunetto, Y. (2007). Women entrepreneurs, opportunity recognition and government-sponsored business networks: A social capital perspective. Women in Management Review, 22(3), 187-207.

Fogelberg Eriksson, A. (2014). A Gender perspective as trigger and facilitator of innovation. International Journal of gender and Entrepreneurship, 6(2), 163-180.

Fossen, F.M. (2012). Gender differences in entrepreneurial choice and risk aversion - a decomposition based on a microeconometric model. Applied Economics, 44(14), 1795-1812.

Frietsch, R., Haller, I., Funken-Vrohlings, M. \& Grupp, H. (2009). Gender-specific patterns in patenting and publishing. Research Policy, 38(4), 590-599.

Gender and Excellence in the Making (2004). European Commission.

Gendered Innovations How Gender Analysis Contributes to Research (2013). Directorate General for Research \& Innovation EUR 25848 Report of the Expert Group Innovation through Gender.

Gicheva, D. \& Albert N. (2011). Leveraging entrepreneurship through private investments: does gender matter? Small Business Economics, 40(2), 199-210.

Guan, J. \& Chen K. (2012). Modeling the relative efficiency of national innovation systems. Research Policy, 41(1), 102-115.

Hausmann, R. (2014). Gender Gap Report 2014. 
Hessels, J., Gelderen, M. \& Thurik, R. (2008). Entrepreneurial aspirations, motivations, and their drivers. Small Business Economics, 31(3), 323-339.

Hsieh, Ch.-T., Hurst, E., Jones, Ch.I. \& Klenow, P.J. (2013). The allocation of talent and U.S. economic growth. Working Paper, 18693. National Bureau of Economic Research.

Hunt, J., Garant, J.-P., Herman, H. \& Munroe, D.J. (2013). Why are women underrepresented amongst patentees? Research Policy (Elsevier), 42(4), 831-843.

International Monetary Fund (2013). Women, Work, and the Economy: Macroeconomic Gains From Gender Equity. IMF Staff Discussion Note.

Jovanovic, B. (1994). Firm formation with heterogeneous management and labour skills. Small Business Economics, 6(3), 185-191.

Klapper, L.F., \& Parker, S.C. (2011). Gender and the business environment for new firm creation. World Bank Research Observer, 26(2), 237-257.

Klasen, S. (2002). Low schooling for girls, slower growth for all? Cross-country evidence on the effect of gender inequality in education on economic development. The World Bank Economic Review, 16(3), 345-373.

Klasen, S. \& Lamanna, F. (2009). The impact of gender inequality in education and employment on economic growth: new evidence for a panel of countries. Feminist Economics, 15(3), 91-132.

Kvidal, T. \& Ljunggren, E. (2014). Introducing gender in a policy programme: a multilevel analysis of an innovation policy programme. Environment and Planning C: Government and Policy, 32(1), 39-53.

Lindberg, M. (2010). Doing gender in Sweden's innovation policy when transforming academic theory into regional practice. Equality, Growth and Sustainability Do They Mix?, 65.

Lindberg, M. (2014). From exclusion to inclusion in public innovation support? Innovative practices in bottom-up networks. Scandinavian Journal of Public Administration, 18(4), 91-107.

Lindberg, M., Lindgren, M. \& Packendorff, J. (2014). Quadruple Helix as a way to bridge the gender gap in entrepreneurship: the case of an innovation system project in the Baltic Sea Region. Journal of the Knowledge Economy, 5(1), 94-113.

Littunen, H. (2000). Entrepreneurship and the characteristics of the entrepreneurial personality. International Journal of Entrepreneurial Behavior \& Research, 6(6), 295-310.

Ljunggren, E., Alsos, G.A., Amble, N., Ervik, R., Kvidal, T. \& Wiik, R. (2010). Gender and innovation. Learning from regional VRI-projects. NF-report, 2, 2010.

Lucas, R.E. (1978). On the size distribution of business firms. Bell Journal of Economics, 9(2), 508-523. 
Lundvall, B.-A., Johnson, B., Sloth Andersen, E. \& Dalum, B. (2002). National systems of production. Innovation and Competence Building. Research Policy, Innovation Systems, 31(2), 213-231.

Maddox, B., Mcelheny, V.K. (2003). Rosalind Franklin: The dark lady of DNA. Journal of the History of Biology, 36(3), 591-597.

Minniti, M., Arenius, P. \& Langowitz, N. (2005). Global Entrepreneurship Monitor: 2004 Report on women and entrepreneurship. Centre for women's leadership at Babson College. London: London Business School.

Morris, M.H., Miyasaki, N.N., Watters, C.E. \& Coombes, S.M. (2006). The dilemma of growth: understanding venture size choices of women entrepreneurs. Journal of Small Business Management, 44(2), 221-244.

Nählinder, J. (2010). Where are all the female innovators? Nurses as innovators in a public sector innovation. Journal of Technology Management \& Innovation, 5(1), 13-29.

Nählinder, J., Tillmar, M. \& Wigren, C. (2015). Towards a gender-aware understanding of innovation: a three-dimensional route. International Journal of Gender and Entrepreneurship, 7(1), 66-86.

Nählinder, J., Tillmar, M. \& Wigren-Kristoffersson, C. (2012). Are Female and Male Entrepreneurs Equally Innovative? Reducing the Gender Bias of Operationalisations and Industries. In: S. Andersson, K. Berglund, E. Gunnarsson \& E. Sundin (eds.), Promoting Innovation: Policies, Practices and Procedures (pp. 66-86). Vinnova Report 2012:08.

OECD and Eurostat (2005). Oslo Manual. Paris: Organisation for Economic Co-operation and Development.

OECD (2006). Economic Policy Reforms: Going for Growth. OECD Publishing, Paris. Pettersson, K. (2007). Men and Male as the Norm?: A Gender Perspective on Innovation Policies in Denmark, Finland and Sweden. Nordregio.

Powell, G.N., Butterfield, D.A. \& Parent, J.D. (2002). Gender and managerial stereotypes: have the times changed? Journal of Management, 28(2), 177-193.

Promoting Innovation - Vinnova (2015). [Online] Retrieved from: http://www.vinnova. se/en/Publications-and-events/Publications/Products/Promoting-Innovation/ (access: 19.06.2016).

Reindustrialising Europe Member States' Competitiveness Report 2014 SWD(2014) 278.

Rosen, S. (1982). Authority, control, and the distribution of earnings. Bell Journal of Economics, 13(2), 311-323.

Rost, K. (2011). The strength of strong ties in the creation of innovation. Research Policy, 40(4), 588-604.

Roy, A.D. (1951). Some thoughts on the distribution of earnings. Oxford Economic Papers, New Series, 3(2), 135-146. 
Ruest-Archambault, E. (2008). Benchmarking Policy Measures for Gender Equality in Science. Luxembourg: Office for Official Publications of the European Communities.

Samson, A.E.S. (2006). Gender and Science, Technology, and Innovation. UNCTAD Current Studies on Science, Technology and Innovation, No. 5.

Sauer, R.M. \& Wilson, T. (2015). The Rise of Female Entrepreneurs: New Evidence on Gender Differences in Liquidity Constraints. IZA Discussion Paper 8981. Institute for the Study of Labor (IZA).

Schein, V.E. (2007). Women in management: reflections and projections. Women in Management Review, 22(1), 6-18.

Schiebinger, L. \& Schraudner, M. (2011). Interdisciplinary approaches to achieving gendered innovations in science, medicine, and engineering. Interdisciplinary Science Reviews, 36(2).

She Figures (2012). European Commission.

Sime, R.L. (1996). Lise Meitner: A Life in Physics. California Studies in the History of Science. Berkeley: University of California Press.

Thévenon, O., Nabil, A., Adema, W. \& Salvi del Pero, A. (2012). Effects of Reducing Gender Gaps in Education and Labour Force Participation on Economic Growth in the OECD. OECD Social, Employment and Migration Working Papers. Paris: OECD.

Turner, L. (2009). Gender diversity and innovative performance. International Journal of Innovation and Sustainable Development, 4(2-3), 123-134.

UN Report: Innovation and Women's Entrepreneurship: An Exploration of Current Knowledge, Presented to United Nations Conference on Trade and Development Prepared by Womenable, Final Draft, May 2010.

Whittington, K.B. (2011). Mothers of invention? Gender, motherhood, and new dimensions of productivity in the science profession. Work and Occupations, 38(3), 417-456.

Women and Science. Mobilising women to enrich European research COM(99)76 final. World Bank (2001). Engendering Development. Washington, DC: World Bank.

World Bank (2011), World Development Report 2012. Gender Equality and Development. Washington, DC: World Bank.

Yi, Y.-A. (1996). Margaret G. Reid: life and achievements. Feminist Economics, 2(3), 17-36. 


\title{
POLITYKI DOTYCZACE INNOWACJI I PRZEDSIĘBIORCZOŚCI A RÓWNOŚĆ PKCI
}

\begin{abstract}
Abstrakt
Tło badań. Nierówności ze względu na płeć hamują wzrost gospodarczy zmniejszając pulę potencjalnych talentów poprzez hamowanie dostępu jednej płci do edukacji, zatrudnienia, przedsiębiorczości i tworzenia innowacji. Badania nad politykami dotyczącymi przedsiębiorczości, innowacji i płci mają ogromne znaczenie dla wyboru najlepszej kombinacji polityk w celu zmniejszenia strat dobrobytu wynikajacych z nierówności płci.
\end{abstract}

Cel badań. Celem niniejszej pracy jest zbadanie, w jaki sposób polityki odnoszące się do innowacji i przedsiębiorczości w Europie podejmują kwestię równości płci. Pytanie, które stawiamy, to: czy polityki dotyczące przedsiębiorczości i innowacji są ukierunkowane na równość płci, neutralne pod względem płci, czy pośrednio dyskryminujące ze względu na płeć?

Metodyka. Skupiamy się na wspólnym obszarze obejmującym innowacje, przedsiębiorczość i równość płci. Analizujemy modele systemów innowacji: Narodowe Systemy Innowacji, Modele Potrójnej Helisy i Poczwórnej Helisy, i omawiamy, czy podejmują one kwestie równości płci w innowacjach.

Kluczowe wnioski. Twierdzimy, że w politykach odnoszacych się do innowacji i przedsiębiorczości brakuje perspektywy płci. Polityki dotyczące innowacji w Europie nakierowane są na gałęzie przemysłu z przewaga mężczyzn w zatrudnieniu. Konkludujemy, że polityki w zakresie przedsiębiorczości i innowacji, oparte na naukowych dowodach, powinny uwzględniać równość płci jako swoją cechę strukturalna.

Słowa kluczowe: polityka, przedsiębiorczość, innowacja, nierówność płci, Narodowy System Innowacji, Model Potrójnej Helisy, Model Poczwórnej Helisy. 